\title{
Pengembangan Multimedia Interaktif Sport massase Untuk Mahasiswa Pendidikan Jasmani Dan Kesehatan FIK-UM
}

\author{
Development of Interactive Multimedia Sport massase for Physical \\ Education and Health Students of FIK-UM
}

Ari Wibowo Kurniawan

Fakultas Ilmu Keolahragaan, Universitas Negeri Malang, Jl. Semarang No. 5, Sumbersari, Kec. Lowokwaru, Kota

Malang, Jawa Timur, 65145, Indonesia

e-mail: ari.wibowo.fik@um.ac.id

\begin{abstract}
Abstrak
Tujuan penelitian adalah mengembangkan multimedia interaktif sport massase agar pembelajaran efektif untuk mahasiswa pendidikan jasmani dan kesehatan FIK-UM. Metode penelitian menggunakan Lee \& Owen dengan tahap: (1) analisis, (2) desain, (3) pengembangan, validasi, dan revisi, (4) implementasi/uji coba, (5) evaluasi. Hasil uji ahli diperoleh: (1) ahli sport massase $88,88 \%$, (2) ahli media 90,62\%. Uji coba kelompok kecil dengan 7 mahasiswa diperoleh 80,56\%, dan kelompok besar dengan 30 mahasiswa diperoleh $85,46 \%$. Dapat disimpulkan pembelajaran multimedia interaktif mendorong mahasiswa belajar dengan media baru dengan memanfaatkan teknologi sehingga dapat memfasilitasi dan mengatasi kesulitan-kesulitan mahasiswa dalam pembelajaran sport massase menggunakan multimedia interaktif.
\end{abstract}

Kata kunci: Multimedia Interaktif, Sport massase, Mahasiswa Pendidikan Jasmani

\begin{abstract}
The research objective is to develop interactive sports massase multimedia so that effective learning for physical education and health students of FIK-UM. The method used Lee \& Owen with stages: (1) Analysis (2) Design (3) Development, validation, and revision (4) Implementation / Trial (5) Evaluation. Expert test results were obtained: (1) 88.88\% of mass sport experts, (2) $90.62 \%$ of media experts. Small group trials with 7 students gained $80.56 \%$, large group trials with 30 students gained $85.46 \%$. The conclusion of the research is interactive multimedia learning encourages students to learn with new media by utilizing technology so that it can facilitate and overcome student difficulties in learning massase sports using interactive multimedia.
\end{abstract}

Keywords: Interactive Multimedia, Sport massase, Physical Education Students

corresponding author: ari.wibowo.fik@um.ac.id

Artikel Info:

Submitted: $\mathbf{2 7 / 0 1 / 2 0 2 1}$

Revised : 18/02/2021

Accepted : 19/02/2021

Published: 17/05/2021

\section{@)}

Journal Coaching Education Sports is licensed under a Creatives Commons Attribution 4.0 International License

Copyright @ 2021 


\section{A. Pendahuluan}

Undang-Undang Republik Indonesia Nomor 3 tahun 2005 tentang sistem keolahragaan nasional (UU-SKN), pasal 1 ayat 1 dijelaskan bahwa "keolahragaan adalah segala aspek yang berkaitan dengan olahraga yang mememerlukan pengaturan, pendidikan, pembelajaran, pembinaan, pengembangan, dan pengawasan" (UU No 3 Tahun 2005, 2005). Dari pasal ini dapat diaplikasikan ke dalam dunia pendidikan, bahwa untuk menguasai dan memperdalam ilmu keolahragaan perlu pembelajaran. Dan pembelajaran tersebut harus didesain dengan proses dan variasi yang efektif dan efisien, sehingga peserta didik akan lebih maksimal dalam memperoleh pengetahuan tentang keolahragaan yang dipelajarinya. Saat ini, pembelajaran tentang olahraga dapat dicapai melalui pengetahuan modern. Dalam aktivitas olahraga, ada langkahlangkah keamanan yang dapat dilakukan untuk menghindari cedera (Sagala \& Daulay, 2020). Selain melakukan pemanasan dapat juga dibantu dengan treatment sport massase.

Massase merupakan salah satu di antara cara-cara perawatan tubuh yang paling tua dan paling bermanfaat dalam perawatan fisik (badan). Di panti messase bisa digunakan untuk kesehatan dan kecantikan. Pengetahuan tradisional diperlukan menguasai teknik messase (ilmu urai tubuh) dan latihan melakukan gerakan massase yang cukup banyak (Supriyadi \& Wadani, 2012).

Massase mengarahkan penerapan manipulasi (penanganan) perawatan dari bagian luar kepada tubuh. Massase selalu harus ditunjukkan pada kulit dengan menggunakan cream massase. Penggunaan krim lebih baik untuk gerakan terbaik dan mencegah gelembung/kerusakan pada kulit dan kulit.

(Sulistyorini \& Basoeki, 2012) menjelaskan macam-macam massase yang dapat diberikan pada seseorang antara lain: (a) massase therapeutic (pengobatan) yang bertujuan untuk penyembuhan, dalam arti dengan memberikan massase orang ingin mendapatkan pengaruh yang sebaikbaiknya terhadap keadaan pathologis maupun postraumatis, (b) beauty massase atau cosmetik massase diberikan di salonsalon kecantikan dengan tujuan untuk memperbaiki peredaran darah, merawat dan mencegah timbulnya keriput atau lipatan pada kulit terutama pada wajah, (c) hygiene massase diberikan pada pegawai atau pekerja yang dalam melakukan pekerjaannya banyak duduk, berdiri atau terlalu sibuk, (d) waktu olahraga diketahui bermanfaat bagi manusia dengan mendinginkan atau menghihlangkan rasa penat untuk memperbaiki kondisi tubuh manusia, untuk membantu prestasi olahragawan, untuk membantu 
mempercepat penyembuhan cedera tertentu.

Mahasiswa Pendidikan Jasmani dan Kesehatan FIK-UM dalam mempersiapkan diri untuk terjun kemasyarakat perlu dibekali berbagai keterampilan disamping penguasaan teori juga keterampilan dalam mempraktekan semua yang tersusun dalam kurikulum. Salah satu mata kuliah praktek yang harus dikuasai adalah massase. Pada matakuliah massase mempunyai kontribusi penting dalam mempertahankan dan meningkatkan kondisi tubuh seseorang. Masalah dengan pertemuan adalah siswa perlu dimotivasi saat melaksanakannya. Untuk mendapatkan hasil terbaik, membutuhkan keterampilan yang tepat dan strategi yang tepat. Untuk itu perlunya kemampuan seorang dosen untuk mendesain program pembelajaran yang bervariasi, menarik dan aman untuk dilakukan oleh mahasiswa.

Pembelajaran materi massase pada saat ini masih belum maksimal, ini salah satunya diakibatkan karena model pembelajaran yang diberikan ke mahasiswa masih konvensional dan kurang dalam menerapkan pembelajaran XXI dengan memanfaatkan IPTEK, oleh sebab itu penggunaan IPTEK dalam peningkatan kemampuan mahasiswa saat ini harus dilakukan. Untuk itu, pola pikir kita harus dirubah agar maju dengan menggunakan bantuan teknologi, sehingga kemampuan mahasiswa dalam menguasai materi massase dapat lebih meningkat. Hal ini diperkuat dengan pernyataan (Pujianto et al., 2020) bahwa pemanfaatan berbagai macam sumber belajar merupakan upaya dalam pemecahan masalah belajar. Kesadaran tentang kebutuhan teknologi harus dimiliki oleh calon guru pendidikan jasmani (Kalemoğlu Varol, 2014).

Menurut (Vernadakis et al., 2012) bahwa penggunaan teknologi dalam pembelajaran menarik minat dan respek siswa terhadap proses pembelajaran jika dibandingkan dengan pembelajaran kovensional. (Arda et al., 2013) menjelaskan bahwa pendidikan diperlukan pembaharuan dalam hal media pembelajaran agar menarik menjadi lebih efisien, efektif, dan relevan dengan perkembangan iptek. Salah satu teknologi yang dapat meningkatkan hasil belajar adalah multimedia interaktif selaras dengan penelitian dari (Wiendartun et al., 2007) bahwa pembelajaran berbasis multimedia berpengaruh terhadap peningkatan hasil belajar.

(Barbee \& Lowenstein, 2015) berpendapat bahwa multimedia digunakan untuk mendefinisikan area yang sangat luas yang mencakup bidang informatika, telekomunikasi, sektor produksi audio visual, bioskop dan digital media. 
(Maulana et al., 2018) menjelaskan bahwa multimedia interaktif dapat juga dipandang sebagai upaya pemanfaatan komputer untuk membuat dan menggabungkan teks, grafik, audio, gambar bergerak (video dan animasi) dengan menggabungkan link dan tool yang memungkinkan pemakai untuk melakukan navigasi, berinteraksi, berkreasi dan berkomunikasi baik dalam konteks face to face, offline konteks, maupun online konteks. Pendapat lain disampaikan oleh (Munir, 2020) multimedia interaktif adalah suatu tampilan multimedia yang dirancang oleh desainer agar tampilannya memebuhi fungsi menginformasikan pesan dan memiliki interaktifitas kepada pengguna.

(Dwiyogo, 2008) menjelaskan bahwa multimedia interaktif merupakan sistem media penyampaian yang menyajikan materi video rekaman dengan pengendalian komputer kepada penonton yang tidak hanya mendengar dan melihat video dan suara, tetapi juga memberikan respon yang aktif dan respon itu yang menentukan kecepatan dan sekuensi penyajian. (Daryanto, 2015) multimedia interaktif adalah suatu multimedia yang dilengkapi alat pengontrol yang dapat dioperasikan pengguna sesuai dengan yang dikehendakinya.

(Cairncross \& Mannion, 2001) menjelaskan kelebihan multimedia interaktif adalah memberikan pembelajaran sehingga membuat siswa tidak bosan dengan adanya unsur teks, gambar, dan video. Sedangkan (Munir, 2020) menjelaskan keunggulan multimedia interaktif adalah: (1) sistem pembelajaran inovatif dan interaktif, (2) menggabungkan teks, gambar, dan video, (3) menambah motivasi peserta didik, (4) mampu menvisualisasikan materi yang selama ini sulit diterangkan. (Prasetio et al., 2014) menjelaskan dengan menggunakan metode multimedia interaktif dalam pembelajaran dapat meningkatkan hasil belajar peserta didik serta proses pembelajaran dapat berjalan dengan sempurna dan efektif. (Prasetio et al., 2014) menjelaskan bahwa kelebihan multimedia interaktif adalah menggabungkan berbagai macam media serta dapat digunakan untuk pembelajaran mandiri maupun klasikal sehingga peserta didik dengan berbagai tingkatan kemampuan dapat menggunakan tanpa merasa kesulitan karena dilengkapai dengan petunjuk penggunaan.

Hasil penelitian (Ampa, 2015) menunjukkan bahwa dengan menggunakan materi pembelajaran dalam bentuk multimedia interaktif, siswa dapat termotivasi untuk belajar. (Arda et al., 2013) menyatakan bahwa media pembelajaran yang menggunakan multimedia interaktif dapat meningkatkan pemahaman konsep. (Gilakjani, 2012) menyebutkan bahwa ada tiga alasan dan 
alasan penggunaan multimedia di kelas, diantaraya penggunaannya meningkatkan tingkat minat siswa, meningkatkan pemahaman mereka, dan meningkatkan kemampuan menghafal siswa.

Berdasarkan hasil analisis kebutuhan dengan observasi pada mata kuliah massase pada April 2019: (1) belum pernah digunakannya media pembelajaran dalam perkuliahan massase, (2) mahasiswa merasa belum menguasai benar teknikteknik sport massase karena hanya dilakukan secara konvensional karena gaya belajar tiap mahasiswa berbeda, (3) perlu adanya pengembangan media pembelajaran dalam matakuliah massase, (4) perlu adanya pengembangan sport massase dikemas dalam multimedia interaktif dengan memanfaatkan laptop yang hampir dimiliki oleh setiap mahasiswa.

Berdasarkan teori yang dipaparkan pada latar belakang dan diperkuat dengan temuan-temuan di lapangan yang didapat dari hasil analisis kebutuhan maka diperlukan inovasi pembelajaran pada massase menggunakan multimedia interaktif. Hasil pembelajaran yang sedang dikembangkan ini dapat membantu mahasiswa untuk menguasai keterampilan teknik-teknik sport massase dan dikemas semenarik mungkin agar dapat memudahkan mahasiswa. untuk itu peneliti akan mengembangkan penelitian dengan judul "Pengembangan Multimedia Interaktif Sport massase untuk Mahasiswa Pendidikan Jasmani dan Kesehatan FIKUM".

Tujuan penelitian dan pengembangan ini adalah mengembangkan multimedia interaktif sport massase untuk mahasiswa Pendidikan Jasmani dan Kesehatan FIKUM untuk meningkatkan pemahaman dan keterampilan mahasiswa tentang sport massase.

\section{B. Metode Penelitian}

Penelitian dan pengembangan pembelajaran sport massase menggunakan multimedia interaktif untuk mahasiswa Pendidikan Jasmani dan Kesehatan (PJK) Universitas Negeri Malang (UM) ini, secara khusus ada beberapa tujuan, yaitu: (1) untuk memperoleh informasi secara mendalam tentang proses pelaksanaan pembelajaran sport massase menguasai teknik-teknik yang ada dalam sport massase, (2) mengembangkan dan menerapkan proses pembelajaran sport massase untuk mahasiswa, (3) memperoleh data empiris tentang efektifitas, efisiensi dan daya tarik hasil pengembangan pembelajaran sport massase untuk mahasiswa Pendidikan Jasmani dan Kesehatan FIK-UM. Tujuan akhir dari penelitian pengembangan ini 
E-ISSN: 2722-3450 P-ISSN:2775-3808

adalah menghasilkan produk berupa model pembelajaran sport massase menggunakan multimedia interaktif untuk mahasiswa Pendidikan Jasmani dan Kesehatan FIKUM, sehingga dapat melengkapi bantuan belajar yang ada pada saat ini.

Penelitian dilaksanakan di Universitas Negeri Malang. Fakultas Ilmu Keolahragaan Pendidikan Jasmani dan Kesehatan. Waktu penelitian selama 4 bulan yaitu pada Agustus sampai dengan November 2019. Penelitian dan pengembangan pembelajaran sport massase untuk mahasiswa Pendidikan Jasmani dan Kesehatan FIK-UM dikemas dalam multimedia interaktif menggunakan pendekatan Research and Development (R\&D) dengan menggunakan model pengembangan untuk multimedia yang dikembangkan oleh (W. Lee \& L. Owens, 2004). Tahap-tahap penelitian ini adalah analisis, desain, pengembangan, implementasi, dan evaluasi. Tahap analisis meliputi needs assessment dan front-end analysis. Kegiatan yang dilakukan dalam front-end analysis antara lain audience analisis, technologi analysis, media analisis dan extand-data analysis. Alasan menggunakan model ini karena produk yang dikembangkan berbasis komputer yaitu multimedia interaktif.

Prosedur pengembangan multimedia interaktif sport massase untuk mahasiswa Pendidikan Jasmani dan Kesehatan FIKUM dilakukan dalam beberapa tahap. Tahap dari prosedur terlihat pada Gambar 1.

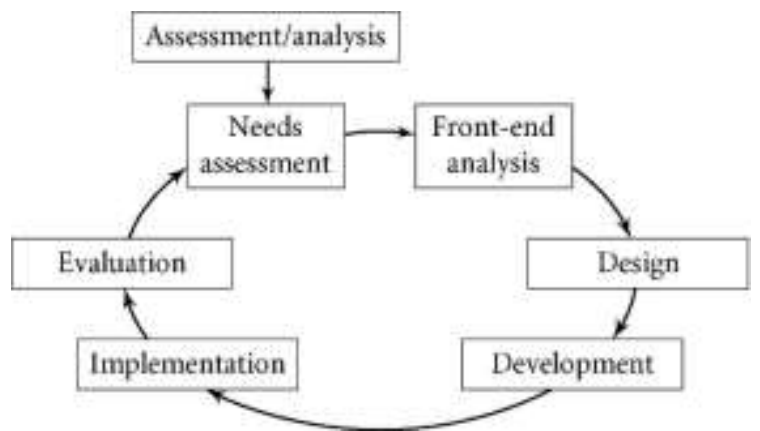

Gambar 1 Model Pengembangan Multimedia Interaktif (Lee \& Owen, 2004:1)

Tahap analisis dibagi menjadi dua bagian yaitu needs assessment dan frontend analysis. Needs assessment merupakan pengumpulan data-data secara keseluruhan yang dapat dijadikan sebagai bahan untuk mengembangkan multimedia interaktif sport massase untuk mahasiswa
Pendidikan Jasmani dan Kesehatan (PJK) Fakultas Ilmu Keolahragaan. Needs assessment dilakukan dengan metode penyebaran angket dan observasi. Frontend analysis menganalisis data-data dan informasi yang benar-benar dibutuhkan. Dalam penelitian ini tahap front-end 
analysis ada beberapa kegiatan yaitu audience analysis untuk menentukan target/sasaran yang akan memakai multimedia interaktif sport massase untuk mahasiswa Pendidikan Jasmani dan Kesehatan (PJK) Fakultas Ilmu Keolahragaan, technology analysis untuk menentukan jenis teknologi (hardware dan software) yang dibutuhkan untuk pengembangan dan menjalankan multimedia interaktif sport massase untuk mahasiswa Pendidikan Jasmani dan Kesehatan (PJK) Fakultas Ilmu Keolahragaan, media analysis menentukan jenis media yang akan dikembangkan, dan extand-data analysis untuk menentukan isi materi yang akan diterapkan dalam aplikasi. Analisis disini merupakan langkah-langkah yang digunakan untuk mengkaji keadaan lapangan dengan tujuan apakah produk yang dikembangkan diterima atau tidak oleh subjek.

Tahap desain merupakan tahap perancangan multimedia interaktif sport massase untuk mahasiswa Pendidikan Jasmani dan Kesehatan (PJK) Fakultas Ilmu Keolahragaan, berdasarkan informasi yang telah didapatkan dari tahap analisis. Meliputi material collecting (mengumpulkan bahan-bahan yang diperlukan untuk mengembangkan multimedia interaktif sport massase untuk mahasiswa Pendidikan Jasmani dan
Kesehatan (PJK) Fakultas Ilmu Keolahragaan, pembuatan storyboard, dan pembuatan flowchart).

Tahap pengembangan ini merupakan tahap dilakukan pengembangan multimedia interaktif sport massase untuk mahasiswa Pendidikan Jasmani dan Kesehatan (PJK) Fakultas Ilmu Keolahragaan sesuai dengan desain yang telah dibuat terdapat beberapa tahapan yaitu, tahap pengembangan, tahap validasi, dan tahap revisi. Tahap pengembangan meliputi pengembangan interface, coding, testing, publising dan pemaketan. Tahap validasi dilaksanakan oleh ahli media dan ahli pembelajaran yang terdapat dalam multimedia interaktif sport massase untuk mahasiswa Pendidikan Jasmani dan Kesehatan (PJK) Fakultas Ilmu Keolahragaan. Revisi dilakukan berdasarkan saran dan pendapat para ahli agar aplikasi menjadi lebih baik.

Tahap ini merupakan tahap uji coba yang dilakukan oleh para peserta. Tahap ini berupa uji coba untuk mengukur bagaimana tanggapan dan penilaian pengguna setelah menggunakan multimedia interaktif sport massase untuk mahasiswa Pendidikan Jasmani dan Kesehatan (PJK) Fakultas Ilmu Keolahragaan yang telah dikembangkan, ditinjau dari berbagai aspek menggunakan angket penilaian. 
Penilaian dilakukan dengan mengolah hasil dari validasi ahli media, ahli pembelajaran sport massase, serta uji coba kepada pengguna. Hal ini dilakukan untuk mengetahui tingkat kelayakan multimedia interaktif sport massase untuk mahasiswa Pendidikan Jasmani dan Kesehatan (PJK) Fakultas Ilmu Keolahragaan yang telah dikembangkan serta tanggapan dan penilaian pengguna setelah menggunakan multimedia interaktif sport massase untuk mahasiswa Pendidikan Jasmani dan Kesehatan (PJK) Fakultas Ilmu Keolahragaan. Selain itu juga dipaparkan kelebihan, kekurangan serta spesifikasi multimedia interaktif sport massase untuk mahasiswa Pendidikan Jasmani dan Kesehatan (PJK) Fakultas Ilmu Keolahragaan.

Uji coba produk ini digunakan untuk mengumpulkan data sebagai dasar menentukan tingkat kelayakan dari produk yang dihasilkan, kelayakan ini meliputi keefektifan, efisiensi dan manfaat dari produk pengembangan. Langkah-langkah dari uji coba produk adalah sebagai berikut: (1) Desain Uji coba dilakukan melalui tahap, yaitu: Evaluasi Ahli dilakukan oleh 2 orang ahli, yaitu satu orang ahli pembelajaran sport massase dan satu orang ahli media. Uji Coba Pengguna dilakukan oleh pengguna atau mahasiswa Pendidikan Jasmani dan Kesehatan (PJK) Fakultas Ilmu Keolahragaan Universitas
Negeri Malang untuk memberi tanggapan dan penilaian tentang produk yang dikembangkan menggunakan angket penilaian, (2) Subjek coba pada penelitian pengembangan ini adalah Ahli Pembelajaran Sport massase, Ahli Media, Subjek pengguna pada uji coba kelompok kecil 7 mahasiswa dan uji coba kelompok besar 30 mahasiswa, (3) Jenis Data: Penilaian terhadap tingkat keefektifan, efisiensi, atau daya tarik pada produk yang dikembangkan oleh peneliti diperoleh dari data kualitatif yang diperoleh dari tinjauan, saran dan evaluasi para ahli dan data kuantitatif berupa pengisian angket oleh mahasiswa Pendidikan Jasmani dan Kesehatan (PJK) Fakultas Ilmu Keolahragaan Universitas Negeri Malang, (4) Instrumen Pengumpulan Data: Teknik pengumpulan data dalam penelitian ini dilakukan dengan dua cara yaitu dengan angket yang berbentuk pilihan ganda yang disertai kolom saran yang ditujukan kepada ahli media dan ahli pembelajaran sport massase, dan angket yang berbentuk pilihan ganda untuk pengguna, (5) Teknik Analisis Data: Teknik analisis data yang digunakan pada penelitian ini menggunakan analisis statistik deskriptif. Teknik pengukuran yang digunakan pada pengumpulan data adalah menggunakan skala Likert. Skala Likert digunakan untuk mengukur sikap, pendapat, dam persepsi seseorang atau sekelompok orang tentang 
fenomena sosial (Sugiyono, 2012). Jawaban setiap item instrumen yang menggunakan skala likert mempunyai gradasi dari sangat positif sampai sangat negatif. Untuk keperluan analisis kuantitatif, jawaban itu dapat diberi skor yang telah ditetapkan yaitu satu, dua, tiga, empat, dan lima. Skala penilaian terlihat pada Tabel 1 untuk skala likert.

\begin{tabular}{llll}
\multicolumn{4}{l}{ Tabel 1 Skala Penilaian Untuk Pernyataan Positif dan Negatif } \\
\hline No & Keterangan & Skor Positif & Skor Negatif \\
\hline 1. & Sangat Setuju & 5 & 1 \\
2. & Setuju & 4 & 2 \\
3. & Ragu-ragu & 3 & 3 \\
4. & Tidak Setuju & 2 & 4 \\
5. & Sangat Tidak Setuju & 1 & 5
\end{tabular}

(Sumber: Sugiyono, 2010:94)

Penghitungan persentase kelayakan digunakan rumus sebagai berikut:

Persentase kelayakan $=\frac{\text { jumlah } \text { skor yang didapat }}{\text { jumlah skor yang diharapkan }} \times 100 \%$

Pembagian kriteria hanya dapat kategori sesuai dengan jumlah skala likert memperhatikan rentang bilangan (Arikunto, 2010). Pembagian persentase persentase. Pembagian persentase kelayakan tercantum pada Tabel 2 sebagai kelayakan $100 \%$ dibagi rata menjadi lima berikut:

Tabel 2 Kategori menurut Arikunto

\begin{tabular}{lll}
\hline No & Persentase (\%) & Kategori \\
\hline 1 & $0-20 \%$ & Kurang Sesuai \\
2 & $21 \%-40 \%$ & Kurang \\
3 & $41 \%-60 \%$ & Cukup \\
4 & $61 \%-80 \%$ & Baik \\
5 & $81 \%-100 \%$ & Sangat Baik \\
\hline
\end{tabular}

(Sumber: Arikunto 2009:44)

\section{Hasil dan Pembahasan \\ Hasil}

Produk awal dari penelitian ini merupakan multimedia interaktif sport massase untuk mahasiswa Pendidikan Jasmani dan Kesehatan (PJK) Universitas Negeri Malang (UM). Multimedia interaktif sport massase ini terdapat materi pokok tetang multimedia interaktif sport

massase untuk mahasiswa Pendidikan Jasmani dan Kesehatan (PJK) Universitas Negeri Malang (UM) yang berisikan materi: (a) hakikat massase, (b) manfaat massase, (c) teknik dalam massase, (d) video massase bagian kepala dan wajah sampai paha dan kaki. 
FIK-UM

E-ISSN: 2722-3450 P-ISSN:2775-3808

Berdasarkan hasil pengumpulan data dari kegiatan uji coba penelitian pengembangan multimedia interaktif sport massase untuk mahasiswa Pendidikan Jasmani dan Kesehatan (PJK) Universitas Negeri Malang (UM) di jurusan/program studi Pendidikan Jasmani dan Kesehatan (PJK) Universitas Negeri Malang (UM). Berikut ini akan disajikan dari data hasil analisis kebutuhan; data hasil tinjauan ahli yang meliputi tinjauan dari 1 ahli pembelajaran sport massase, dan 1 ahli media; uji coba kelompok kecil; dan uji coba kelompok besar. Data uji coba kelompok kecil diperoleh dari 7 mahasiswa yang diambil menggunakan teknik sample bertujuan (purposive sample) dan data uji coba kelompok besar adalah data yang diperoleh dari 30 mahasiswa Pendidikan Jasmani dan Kesehatan (PJK) Universitas Negeri Malang (UM). Selengkapnya dapat dilihat pada Tabel 3.

Tabel 3 Data hasil analisis kebutuhan, hasil evaluasi para ahli, uji coba kelompok kecil, uji coba kelompok besar

\begin{tabular}{ll}
\hline No & Prosedur Pengembangan \\
\hline 1 & Analisis kebutuhan
\end{tabular}

2 Pengembangan produk

3 Hasil evaluasi ahli pembelajaran sport massase

$4 \quad$ Hasil evaluasi ahli media

Temuan

Belum pernah digunakannya media pembelajaran dalam perkuliahan massase.

Mahasiswa merasa belum menguasai secara benar teknik-teknik sport massase karena hanya dilakukan secara konvensional karena gaya belajar tiap mahasiswa yang berbeda.

Mahasiswa sangat memerlukan pengembangan media pembelajaran dalam matakuliah massase.

Perlu adanya pengembangan sport massase yang dikemas dalam multimedia interaktif dengan memanfaatkan laptop yang hampir dimiliki oleh setiap mahasiswa.

Produk yang dikembangkan adalah multimedia interaktif sport massase untuk mahasiswa prohram studi pendidikan jasmani dan kesehatan FIK-UM.

Produk terdiri dari materi hakikat massase, manfaat massase, teknik dalam massase, video teknik massase dari kepala dan wajah sampai kaki dan paha.

Dari evaluasi ahli sport massase diperoleh hasil 90,62\% sehingga sangat baik untuk digunakan.

Dari ahli sport massase diperoleh masukan: desain dan isi dari sport massase yang dikembangkan baik dan tepat digunakan.

Dari evaluasi ahli media diperoleh hasil $88,88 \%$ sehingga produk sangat baik untuk digunakan.

Dari ahli media diperoleh masukan: produk sudah baik untuk digunakan dalam perkuliahan

5 Uji coba kelompok kecil
Hasil uji coba kelompok kecil berjumlah 7 orang mahasiswa dengan jumlah insrumen 9 butir pertanyaan.

Dari hasil uji coba kelompok kecil diperoleh hasil 80,56\% sehingga produk multimedia interaktif sport massase untuk mahasiswa Pendidikan Jasmani dan Kesehatan (PJK) Universitas Negeri Malang (UM) sehingga termasuk dalam klasifikasi sangat baik digunakan.

$6 \quad$ Uji coba kelompok besar

Hasil uji coba kelompok besar berjumlah 30 orang mahasiswa dengan jumlah instrumen 9 pertanyaan.
Dari hasil uji coba kelompok besar diperoleh hasil 85,46\% sehingga produk multimedia interaktif sport massase untuk mahasiswa Pendidikan Jasmani dan Kesehatan (PJK) Universitas Negeri Malang (UM) sehingga termasuk dalam klasifikasi sangat baik digunakan. 
Berdasarkan data yang dikumpulkan dari dari 1 ahli pembelajaran sport massase, dan 1 ahli media, serta hasil uji coba kelompok kecil dan uji coba kelompok besar. Ada beberapa bagian produk perlu direvisi agar produk yang dikembangkan lebih sempurna. Berikut adalah ringkasan pembuatan produk hingga menjadi produk jadi yang telah mendapatkan revisi berdasarkan saran dari para ahli, uji coba kelompok kecil dan uji coba kelompok besar adalah sebagai berikut. (1) saran dari ahli pembelajaran sport massase adalah desain dan teknikteknik massase yang dikembangkan baik dan tepat digunakan, (2) saran dari ahli media adalah langkah-langkah yang digunakan dalam massase cukup mudah untuk dilakukan dan diterapkan ke mahasiswa, (3) uji coba kelompok adalah produk yang dikembangkan menarik dan variatif sehingga dapat digunakan dalam pembelajaran mata kuliah massase. Selebihnya rancangan produk sudah bagus dan menarik, sehingga layak untuk diproduksi.

\section{Pembahasan}

Pada mata kuliah sport massase mempunyai kontribusi penting dalam aktivitas olahraga karena dapat menjadi pencegahan-pencegahan yang dapat dilakukan untuk menghindari cedera.
Selain melakukan pemanasan dapat juga dibantu dengan treatment sport massase. Massase merupakan salah satu di antara cara-cara perawatan tubuh yang paling tua dan paling bermanfaat dalam perawatan fisik (badan). Dalam ilmu tata rias, massase dapat digunakan untuk kesehatan dan kecantikan. Untuk menguasai teknikteknik massase perlu memiliki pengetahuan mengenai anatomi (ilmu urai tubuh) dan latihan melakukan gerakan massase yang cukup banyak (Supriyadi \& Wadani, 2012). Massase mengarahkan penerapan manipulasi (penanganan) perawatan dari bagian luar kepada tubuh. Massase selalu harus ditunjukkan pada kulit dengan menggunakan cream massase. Penggunaan cream mempermudah gerakan tangan yang lebih sempurna, dan mencegah lecet/rusaknya jaringan-jaringan.

Berdasarkan produk yang dikembangakan dalam kenyataannya membutuhkan pengkajian ulang keberadaannya, karena setelah melalui proses penelitian terdapat beberapa hal yang perlu untuk dilakukan perbaikan. Produk pengembangan sport massase untuk mahasiswa pendidikan jasmani dan kesehatan FIK-UM dalam bentuk multimedia interaktif yang dikemas menggunakan DVD memiliki kelebihankelebihan sebagai salah satu alternatif 
E-ISSN: 2722-3450 P-ISSN:2775-3808

yang dapat dimanfaatkan dalam

permasalahan yang terjadi pada proses perkuliahan dengan membuat pembelajaran yang memudahkan mahasiswa pada mata kuliah massase dan dengan memanfaatkan kemajuan teknologi.

Pembelajaran materi massase pada saat ini masih belum maksimal, ini salah satunya diakibatkan karena model pembelajaran yang diberikan ke mahasiswa masih konvensional dan kurang dalam menerapkan pembelajaran XXI dengan memanfaatkan IPTEK. Oleh sebab itu penggunaan IPTEK dalam peningkatan kemampuan mahasiswa saat ini harus dilakukan. Untuk itu, pola pikir kita harus dirubah agar maju dengan menggunakan bantuan teknologi, sehingga kemampuan mahasiswa dalam menguasai materi massase dapat lebih meningkat. Hal ini diperkuat dengan pernyataan (Pujianto et al., 2020) bahwa pemanfaatan berbagai macam sumber belajar merupakan upaya dalam pemecahan masalah belajar. Kesadaran tentang kebutuhan teknologi harus dimiliki oleh calon guru pendidikan jasmani (Kalemoğlu Varol, 2014).

Menurut (Vernadakis et al., 2012) bahwa penggunaan teknologi dalam pembelajaran menarik minat dan respek siswa terhadap proses pembelajaran jika dibandingkan dengan pembelajaran kovensional. Sedangkan (N, 2013) menjelaskan bahwa pendidikan diperlukan pembaharuan dalam hal media pembelajaran agar menarik menjadi lebih efisien, efektif, dan relevan dengan perkembangan IPTEK. Salah satu teknologi yang dapat meningkatkan hasil belajar adalah multimedia interaktif selaras dengan penelitian dari (Wiendartun et al., 2007) bahwa pembelajaran berbasis multimedia berpengaruh terhadap peningkatan hasil belajar.

Hasil penelitian (Ampa, 2015) menunjukkan bahwa dengan menggunakan materi pembelajaran dalam bentuk multimedia interaktif, siswa dapat termotivasi untuk belajar. (Arda et al., 2013) menyatakan bahwa media pembelajaran yang menggunakan multimedia interaktif dapat meningkatkan pemahaman konsep. Sedangkan (Gilakjani, 2012) menyebutkan bahwa ada tiga alasan dan alasan penggunaan multimedia di kelas, diantaraya penggunaannya meningkatkan tingkat minat siswa, meningkatkan pemahaman mereka, dan meningkatkan kemampuan menghafal siswa.

Dengan menggunakan multimedia interaktif, bentuk-bentuk pembelajaran massase yang dikembangkan memiliki kelebihan memperjelas penyajian pesan agar tidak terlalu bersifat verbalistis (dalam bentuk kata-kata tertulis atau lisan belaka), mengatasi keterbatasan ruang, 
waktu dan daya indera. Penggunaan media secara tepat dan bervariasi dapat mengatasi sikap pasif peserta didik yaitu menimbulkan kegairahan belajar, memungkinkan interaksi yang lebih langsung antara anak didik dengan lingkungan dan kenyataan, memungkinkan anak didik belajar sendiri-sendiri menurut kemampuan dan minatnya, memberikan solusi bila latar belakang lingkungan guru dengan siswa berbeda, dalam hal ini kemampuan media memberikan perangsang yang sama, mempersamakan pengalaman, menimbulkan persepsi yang sama (Sadiman, 2003).

\section{SIMPULAN}

Berdasarkan hasil analisis data dalam penelitian tentang Multimedia Interaktif Sport massase untuk Mahasiswa Pendidikan Jasmani dan Kesehatan FIKUM. Pembuatan produk pengembangan pembelajaran sport massase untuk mahasiswa pendidikan jasmani dan kesehatan FIK-UM dalam bentuk multimedia interaktif yang dikemas menggunakan DVD ini tentu melalui proses sehingga memungkinkan adanya kesalahan dan kekurangan, dan untuk memperoleh produk yang berkualitas, diperlukan faktor-faktor pendukung pula. maka dari itu produk yang dikembangkan mulai dari rancangan produk hingga produk ini terselesaikan masih memerlukan beberapa revisi untuk mendapakan produk yang maksimal. sebagai upaya memaksimalkan produk yang dikembangkan dalam pembuatan produk ini memerlukan evaluasi dari 1 ahli sport massase dan 1 ahli media.

Berdasarkan data hasil evaluasi 2 ahli yaitu, 1 ahli ahli sport massase dan 1 ahli media, serta pengamatan yang dilakukan, maka dihasilkan pengembangan multimedia interaktif sport massase untuk mahasiswa pendidikan jasmani dan kesehatan FIK-UM dalam bentuk multimedia interaktif yang dikemas menggunakan DVD. Hasil penerapan produk pengembangan multimedia interaktif sport massase dinilai efekif karena dapat memberikan kemudahan, rujukan materi, dan pengalaman baru untuk mahasiswa pendidikan jasmani dan kesehatan FIK-UM dalam proses perkuliahan di mata kuliah massase.

Dalam pemanfaatan sangat perlu pertimbangan situasi, kondisi dan sarana prasarana. Untuk memperoleh tujuan yang diharapkan maka dosen diharapkan untuk mampu menguasai materi terlebih dahulu sebelum disampaikan pada mahasiswa, hal tersebut dilakukan jika mahasiswa masih kesulitan saat mempelajarinya secara mandiri khususnya pada materi sport massase. Dalam penyebarluasan produk 
pengembangan ke sasaran yang lebih luas, peneliti memberikan saran, antara lain: (1) sebelum disebarluaskan sebaiknya produk ini dikaji kembali dan disesuaikan dengan keadaan sasaran yang ingin ditinjau, (2) sebelum disebarluaskan sebaiknya produk ini disusun kembali menjadi lebih sempurna, baik itu tentang kemasan tampilan maupun isi dari materi produk yang dikembangkan, (3) sebelum disebarluaskan sebaiknya disosialisasikan kepada pihak-pihak terkait seperti dosen matakuliah terkait dan mahasiswa yang sedang menempuh matakuliah massase. Dalam mengembangkan penelitian ini ke arah lebih lanjut, peneliti mempunyai beberapa saran: (1) hasil pengembangan ini hanya sampai tersusun sebuah produk, belum sampai tingkat efektivitas produk yang dikembangakan jadi sebaiknya dilanjutkan penelitian menganai efektivitas produk yang dikembangkan, (2) peneliti hanya sebatas mengembangkan teknikteknik memijat dalam sport massase dalam multimedia interaktif sehingga diharapkan untuk penelitian selanjutnya mengembangkan penelitian serupa yang lebih variatif, (3) mengembangkan produk dalam bentuk kemasan lainnya agar menjadi lebih lengkap dan menarik dalam matakuliah.

\section{UCAPAN TERIMA KASIH}

Penulis bersyukur kepada Tuhan YME karena telah dipermudah dalam proses penyusunan, penelitian, penulisan hingga publikasi artikel yang berjudul "Pengembangan Multimedia Interaktif Sport massase Untuk Mahasiswa Pendidikan Jasmani dan Kesehatan FIKUM. Oleh karena itu penulis mengucapkan terima kasih kepada semua pihak dalam penyusunan artikel ilmiah ini dan juga seluruh komponen yang terlibat dalam penelitian. Penulis berharap artikel ini dapat bermanfaat untuk mahasiswa, atlet maupun pelaku olahraga lainnya dan dapat dijadikan rujukan serta dikembangkan dalam bidang yang relevan dengan keilmuan dan teori yang ada.

\section{DAFTAR PUSTAKA}

Ampa, A. T. (2015). The Implementation of Interactive Multimedia Learning Materials in Teaching Listening Skills. English Language Teaching, $8(12)$, 56. https://doi.org/10.5539/elt.v8n12p56 Arda, Saehana, S., \& Darsikin. (2013). Pengembangan Media Pembelajaran Interaktif Berbasis Komputer Untuk Siswa Smp Kelas Viii. E-Jurnal Mitra Sains, 3(1), 69-77. https://docplayer.info/29790216Pengembangan-media-pembelajaraninteraktif-berbasis-komputer-untuk$\underline{\text { siswa-smp-kelas-viii.html }}$

Arikunto, S. (2010). Prosedur Penelitian 
Suatu Pendekatan Praktik (edisi revisi 2010). In Jakarta: Rineka Cipta (10th ed.).

Barbee, D. E., \& Lowenstein, R. B. (2015). Interactive Multimedia. In Information Resources Management Journal (Vol. 6, Issue 4). https://doi.org/10.4018/irmj.1993100 $\underline{101}$

Cairncross, S., \& Mannion, M. (2001). Interactive multimedia and learning: Realizing the benefits. Innovations in Education and Teaching International, 38(2), 156-164. https://doi.org/10.1080/14703290110 $\underline{035428}$

Daryanto. (2015). Media Pembelajaran. Sarana Tutorial Nurani Sejahtera.

Dwiyogo, W. D. (2008). Aplikasi teknologi pembelajaran: Pengembangan media pembelajaran pendidikan jasmani dan olahraga / Wasis D. Dwiyogo.

Gilakjani, A. P. (2012). The Significant Role of Multimedia in Motivating EFL Learners' Interest in English Language Learning. International Journal of Modern Education and Computer Science, 4(4), 57-66. https://doi.org/10.5815/ijmecs.2012.0 $\underline{4.08}$

Kalemoğlu Varol, Y. (2014). The Relationship between attitudes Of prospective physical education teachers towards education technologies and computer selfefficacy beliefs. Turkish Online Journal of Educational Technology, 13(2), 157-167.

Maulana, A., Azhari, A., \& Darmawan, A. (2018). Pengembangan Model Latihan Renang Berbasis Mobile Learning Untuk Mahasiswa Pendidikan Jasmani ,. Bravo's Jurnal, 6(4), 150-155. http://www.ejournal.stkipjb.ac.id/inde x.php/penjas/article/view/973

Munir. (2020). Konsep \& Aplikasi Dalam Pendidikan. In Alfabeta, CV. (Vol. 58, Issue 12).

N, E. (2013). Pengembangan Multimedia Interaktif Pada Pembelajaran Kimia Untuk Madrasah Aliyah. Jurnal Inovasi Pendidikan, 2(1), 65-78.

Prasetio, E. F., Dwiyogo, W. D., \& Sudjana, I. N. (2014). Pengembangan Multimedia Interaktif Model Latihan Bertahan ( Defense ) Sepakbola Pada Ekstrakurikuler Sepakbola Di Smp Negeri 15. Pendidikan Jasmani, 26(1), 129-144.

https://doi.org/http://dx.doi.org/10.17 977/pj.v26i1.7735

Pujianto, D., Sutisyana, A., Arwin, A., \& Nopiyanto, Y. E. (2020). Pengembangan Model Latihan Passing Sepakbola Berbasis Sasaran 
E-ISSN: 2722-3450 P-ISSN:2775-3808

Teman. Journal Coaching Education Sports, $\quad 1(1), \quad 1-12$.

https://doi.org/10.31599/jces.v1i1.81

Sadiman, A. S. (2003). Media Pendidikan:

Pengertian, Pengembangan, dan Pemanfaatannya (1st ed.). Rajagrafindo Persada.

Sagala, R. S., \& Daulay, D. E. (2020). Pengembangan Media Bantu Latihan Bertahan Pada Bola Voli Tahun 2019. Journal Coaching Education Sports, 1(2), 115-126.

https://doi.org/10.31599/jces.v1i2.371

Sugiyono. (2012). Metode penelitian kuantitatif dan $R \& D$. Alfabeta.

Sulistyorini, \& Basoeki, H. (2012). Sport Message Seni Pijat Untuk Atlet/Olahragawan Dan Umum. Wineka Media.

Supriyadi, \& Wadani, H. E. (2012). Anatomi Manusia. UM Press.

UU No 3 Tahun 2005. (2005). UndangUndang Republik Indonesia Nomor 3 Tahun 2005 Tentang Sistem Keolahragaan Nasional Dengan. In Presiden RI.

Vernadakis, N., Giannousi, M., Derri, V., Michalopoulos, M., \& Kioumourtzoglou, E. (2012). The impact of blended and traditional instruction in students' performance. Procedia Technology, 1, 439-443. https://doi.org/10.1016/j.protcy.2012. $\underline{02.098}$
W. Lee, W., \& L. Owens, D. (2004). Multimedia-Based Instructional Design: Computer-Based Training, Web-Based Training, Distance Broadcast Training. 445.

Wiendartun, Ramalis, T. R., \& Rochman, H. S. (2007). Pengaruh Pembelajaran Berbasis Multimedia Terhadap Hasil Belajar Fisika. Proceeding of The First International Seminar on Science Education. 